\title{
Corporate Social Responsibility: Its Effect on SMEs
}

\author{
Luis Enrique Valdez Juárez ${ }^{1}$ \\ ${ }^{1}$ Faculty of Business Administration, Guaymas, Sonora, México \\ Correspondence: Luis Enrique Valdez Juárez, Faculty of Business Administration, Guaymas, Sonora, México. \\ E-mail: levaldez@itson.edu.mx
}

Received: June 16, 2017

Accepted: July 6, 2017 Online Published: August 3, 2017

doi:10.5539/jms.v7n3p75

URL: http://doi.org/10.5539/jms.v7n3p75

\begin{abstract}
In recent times, small and medium-sized companies (SMEs) have focused their activities on short-term financial results. Corporate social responsibility (CSR) is among the organizational practices currently being adopted by companies to increase their competitiveness. While some companies implement CSR out of curiosity or because it is aligned with their true social vocation, most embrace it to increase economic and financial performance. Whereas some theories support CSR practices and assert the great benefits these activities can yield, other theories state that management should not allocate resources to CSR actions. Focusing on SMEs, the present study sought to examine the effects of CSR on profitability from three perspectives: the social, the environmental, and the economic dimensions of social responsibility. The sample for this study included 81 companies in the industrial (54.3\%) and services (45.7\%) sectors operating in the south of the state of Sonora (Mexico). Data collection was carried out from August to November, 2013, and used a self-directed survey administered to company managers. Results were analyzed and validated using a variance-based statistical technique focused on structural equation models (SEM); the structured relationships were validated by partial least square (PLS) modeling using the SmartPLS Professional software (version 3.2.6). Our findings provide evidence that social and economic CSR activities have a positive influence on profitability in SMEs. This study contributes to the development of the main literature on CSR practices in their social, environmental, and economic dimensions: firm theory, sustainability theory, and stakeholder theory.
\end{abstract}

Keywords: corporate social responsibility, environmental social responsibility, economic social responsibility, stakeholders, profitability, SME

\section{Introduction}

The economic, sociopolitical, and environmental changes constantly taking place in the world of today have important effects in most organizations (Martínez, Fuentes, \& Delgado, 2015; Werther Jr \& Chandler, 2010). The proliferation of international quality and environmental certifications centered on corporate social responsibility (CSR) reflects the necessity of such certifications to increase competitiveness in companies (Lee, 2008). The literature states that CSR begun to be studied in detail in the mid-twentieth century, and the concept has considerably evolved during the past two decades (Carroll \& Shabana, 2010). However, some theoretical perspectives have centered exclusively on the pursuit of economic and financial performance (Friedman, 2007), and authors such as Kramer \& Porter (2006) and Friedman (2007) argue that some CSR organizational initiatives and practices (e.g., social and altruistic actions) result in less productivity. On the other hand, some researchers embrace theories on CSR practices based on the company's commitment to society and the organization as a means to achieve increased benefits (Bowen, 2013; Fitch, 1976). For instance, Lee (2008) and Carroll \& Buchholtz (2014) report that CSR actions are positively associated with profitability in organizations. To attain such an effect, companies must adopt a CSR model based on four perspectives or categories: economic, legal, ethical, and discretional (philanthropic-altruistic) (Carroll, 1999). Additionally, organizational practices focused on environmental care and protection are important in achieving better organizational results (OECD, 2011). CSR practices carried out by companies include not only legal and economic obligations, but also other responsibilities towards society and involving its participation (Carroll, 2008). In the same order of ideas, scholars agree that CSR results in quantitative and qualitative benefits for organizations, from community well-being, sustainability, labor rights, and human development to corporate profitability (Blowfield \& Murray, 2008; Carroll, 2008). However, CSR in SMEs has received scant attention; there are only a few local comparative case studies (Carroll, 2008; Lee, 2008), mostly centered on very large and companies, specially multinational (Attig, El Ghoul, Guedhami, \& Suh, 2013; Carroll \& Buchholtz, 2014). 
Specifically, company size and resource capabilities have become the main limitations to embrace and develop CSR in SMEs (Jamali, Lund-Thomsen, \& Jeppesen, 2017; Kechiche \& Soparnot, 2012), along with lack of managerial strategic vision, poor activity prioritization, scarce benchmarking practices, excessive regulation, and lack of knowledge interchange (Coppa \& Sriramesh, 2013; Martínez et al., 2015). Companies, and especially SMEs, implement some practices for the sake of novelty instead of long-term strategic vision (Luo, Wang, Raithel, \& Zheng, 2015; Wang \& Bansal, 2012). Hence the importance of research work showing the main CSR activities undertaken by SMEs and studying the results of such actions. The purpose of this study was to examine the effects of CSR on SME profitability considering its three dimensions: societal social responsibility (SSR), environmental social responsibility (EnSR), and economic social responsibility (EcSR). In our study we have chosen to study the social, environmental and economic activities that CSR companies develop. This is mainly due to the fact that most of the empirical studies have addressed these CSR activities to measure their impact on the profitability of organizations known as SMEs (Lozano \& Huisingh, 2011; Maldonado-Guzman, Pinzon-Castro, \& Lopez-Torres, 2016; Marín, Rubio, \& Maya, 2012). In addition the three-dimensional model developed by Carroll (1979) has been one of the most studied and analyzed in the last 10 years by the majority of the academic community. This model encompasses social (ethical-legal), environmental (sustainability) and economic activities. The following are the research questions of the present study:

1) Does SSR have positive effects on profitability in SMEs?

2) Does EnSR have positive effects on profitability in SMEs?

3) Does EcSR have positive effects on profitability in SMEs?

This research is based on a sample of 81 companies in the industrial and services sectors operating in the south of the state of Sonora (Mexico). Results were analyzed and validated using a variance-based statistical technique with structural equation models (SEM); the structured relationships investigated in this study were validated by partial least square (PLS) modeling using the SmartPLS Professional software (version 3.2.6).

The present study is a contribution to the development of firm theory, sustainability theory, and stakeholder theory, and it takes three essential perspectives on CRS: the social, the economic, and the environmental dimensions, which are fundamental in the development and growth of companies in developing countries. In the first place, firm theory argues that it is the business owner, not the market, the agent responsible for coordinating production and in charge of managing resources with the aim of maximizing profits (Fontrodona \& Sison, 2006). In the second place, sustainability theory deals with higher expectations of citizens, consumers, and investors in regard to economic growth, social cohesion, and environment protection (Benn, Dunphy, \& Griffiths, 2014; Lenssen, Gasparski, Rok, Lacy, \& Eberhard-Harribey, 2006). In the third place, stakeholder theory explains why companies should satisfy not only their shareholders, but also a wide range of parties (clients, employees, and suppliers) (Maignan \& Ferrell, 2004; Werther Jr \& Chandler, 2010).

The present article is structured as follows: The first part presents a theoretical review and an empirical review, as well as the development of the hypotheses set forth in the study. The second part accounts for the method employed the configuration and characteristics of the sample, and the measure and justification of study variables. The last section includes our results and main conclusions.

\section{Literature and Development of Hypotheses}

\subsection{CRS and Profitability in Companies}

CRS has long been an essential topic in organizations, but it has also initiated controversies (Carroll \& Shabana, 2010). As yet, there is no widely accepted definition or concept in the literature, supported by experts in the area (Crane \& Matten, 2016). Based on the firm theory, some authors argue that companies have only one responsibility: maximizing their shareholders' or owners' benefits; they claim that social action does not concern business people (Freeman \& Hasnaoui, 2011; McWilliams, Siegel, \& Wright, 2006; Pedersen, 2010); the free market, governments, and institutional laws are responsible for addressing and solving the social problems of communities, regions, and countries (Friedman, 2007). Mainly due to lack of experience, organizational management should not be focused on social practices, but on their set of management skills to administrate financial and human resources (Freeman \& Liedtka, 1991; Freeman \& Velamuri, 2008; Grant, 2016). As a consequence, companies who spend their energy in CSR activities lose strength and exclude themselves from more competitive global markets (Krüger, 2015; Porter \& Kramer, 2011). From the perspective of stakeholder theory and sustainability, CSR consists in meeting society's expectations about the economic, legal, ethical, social, and philanthropic activities carried out by an organization (Carroll, 1999; Carroll \& Shabana, 2010). 
Recently, the literature has begun to discuss topics such as investing in the community, environmental management, sustainability, human rights, labor rights, market relationships, and corruption in companies and the government (Blowfield \& Murray, 2008; Carroll \& Buchholtz, 2014). Although in the literature there are different models to incorporate and measure CSR in large companies, the most important thing for SMEs is to assimilate these models and try to obtain the same results as in large corporations. Most of these models are based on activities, social, environmental (ethical-legal) and economic (Geva, 2008; Ma, 2012). Topics and variables that are analyzed mainly in the theory of the Stakeholders, theory of the signature and theory of the sustainability (O'riordan \& Fairbrass, 2008).

Large companies and SMEs in our modern times, immersed in demanding and ever changing markets, pursue a balance between their social and economic aspects, and do not disregard sustainability actions (Bhimani, Silvola, \& Sivabalan, 2016; Crane \& Matten, 2016). The social aspect includes actions regarding corporate ethics, values, and the well-being of workers and society by way of altruistic actions (Carroll \& Shabana, 2010; Carroll, 2011), whereas sustainability refers to practices and legal regulations executed and observed by companies in order to preserve the natural environment (Carroll \& Buchholtz, 2014). Specifically, EcSR practices reflect and represent the results of an adequate corporate image and reputation (Blowfield \& Murray, 2014; Martínez et al., 2015). Empirical studies have shown that various social actions performed by companies, for instance practicing values, enforcing corporate ethics, and paying decent salaries to their employees, lead organizations to market competitiveness and to significant financial performance in the long term (Beal, 2013; Virvilaite \& Daubaraite, 2015). Moreover, recent research on SMEs in different regions report that CSR is considered a determining strategy to achieve positive financial and non-financial outcomes in the medium and long term (Castejón \& López, 2016; El Baz, Laguir, Marais, \& Staglianò, 2016).

H1. The development of CSR social practices increases profitability levels in SMEs.

For companies, and specially for SMEs, sustainability has been a central issue for decades, although it has been increasingly addressed by recent literature dealing with its implications and controversies (Benn et al., 2014). Sustainability theory is one of the main streams of literature focusing not only on investors, but also on the well-being of citizens and clients in the form of practices aimed at preserving natural ecosystems (Benn et al., 2014; Lenssen et al., 2006). Based on the theory of sustainability, companies seek a balance between social, environmental and economic (Banerjee, 2008). These activities make organizations into social entities with ethical foundations and values focused on the sustainable development of communities (Garriga \& Melé, 2004). Due to the high costs and complicated government legislations involved, implementing these practices is not easy for SMEs (Bos-Brouwers, 2010; Hoogendoorn, Guerra, \& van der Zwan, 2015). Nevertheless, stakeholders have obtained important social, organizational, and financial results since their companies have adopted CSR actions focused on the environment (Johnson, 2015; Moore \& Manring, 2009).

\section{H2. The development of CSR environmental actions increases profitability levels in SMEs.}

EcSR activities are related with observance of the law, allocation of human and financial resources to improve production and service processes, and the constant practice of corporate ethics (Friedman, 2006). However, the adoption of CSR is subjected to organizational structure and management traits and behaviors, for instance size of the company, whether it is a family business or not, and the gender, professional background, values, and ethics of the manager (Castejón \& López, 2016; Lepoutre \& Heene, 2006). From the theoretical stream of the firm and the stakeholders, companies invest in internal and external activities of social responsibility to generate profitability (cost-benefit) (McWilliams et al., 2006). This investment focuses on profitable actions that the company manager aims to recover in the short term (McWilliams \& Siegel, 2001). Companies that meet social expectations, such as human capital development, customer satisfaction, and shared benefits for stakeholders, can not only secure a positive image, but can also increase wealth created by the organization (Chaudhri, 2016; Jorge, Madueño, Cejas, \& Peña, 2015). Other authors describe the organizational strain of deploying CSR in SMEs, and the need for enough resources to achieve important financial results, such as increased sales and profits for the investors (Ejdys, 2014, 2017; Madorran \& Garcia, 2016). In addition, we can argue that firms because of their size, return on investment and their productivity, it is difficult to infer the significant relationship between these variables. However, in the study developed by Soytas, Denizel, \& Usar (2016), they argue that sustainability and environmental actions are positively associated with financial results. We have thus formulated the following hypothesis:

H3. The development of CSR economic practices increases profitability levels in SMEs.

\section{Methodology}

The sample was structured according to the principles of finite population stratified sampling. The population 
consisted of SMEs operating in the south of the state of Sonora (México), and it was segmented according to their type of economic activities. The number of companies in each strata was based on information from the economic census provided by the National Statistic Directory of Economic Units (DENUE), ran by the National Institute for Statistics and Geography (INEGI, 2014). The sample was composed of SMEs employing from 5 to 240 employees. The average number of the company based on the number of employees is 124 . The youngest company in the sector is 1 year and the oldest company is 87 years. Sample size was determined so as to make the maximum margin of error when estimating a proportion (relative frequency of response to a specific item in a question) be less than 0.03 points, with a $95 \%$ confidence level. Information was gathered by means of personal interviews (questionnaires) with SME managers. Data gathering took place from August to November, 2013. The final sample included 81 companies, $54.3 \%$ from the industrial sector and $45.7 \%$ from the services sector. The composition and characteristics of the sample can be appreciated in table 1. Companies that declined participation in the study were replaced by similar, randomly chosen companies performing the same economic activities and in the same geographical area. Non-response bias was analyzed (Nwachukwu, Vitell, Gilbert, \& Barnes, 1997). Response effectiveness during the first round of interviews represented $80 \%$ of the sample; these results were compared with those of respondents included by replacement ( $20 \%$ of sample); according to $t$ and chi-square tests, there were no significant differences between the groups. In addition, common method variance (CMV) bias was ana-lyzed, since the data came from a single source of information through a single questionnaire. It is possible that the relationships between the variables were inflated as a consequence of CMV. To identify the existence of such bias, we used Harman's single-factor test, as suggested by Podsakoff and Organ (1986) and Reio Jr (2010). The variance explained by the factors in our study is over $71.2 \%$. The four theory constructs in the model are clearly identified in factor analysis (KMO: 0.788; Bartlett sphericity test 0.000). These results all suggest that the common method bias was not a big concern in our study.

Table 1 . Total companies by activity

\begin{tabular}{lcccc}
\hline Sector & Number of employees (5 to 50) & Number of employees (51 to 250) & $\begin{array}{c}\text { Number } \\
\text { of companies }\end{array}$ & $\begin{array}{c}\text { Total } \\
\text { percentage }\end{array}$ \\
\hline Industrial & 11 & 33 & 44 & 54.3 \\
Services & 22 & 15 & 37 & 45.7 \\
\hline Total & 33 & 48 & 81 & 100.0 \\
\hline
\end{tabular}

Note. Small firm: from 5 to 50 employees, Medium-sized firm: from 51 to 250 employees.

\subsection{Variable Measurement}

One most critical criterion to correctly analyze the variables of the model is to understand the nature and direction of causality between the constructs (Vinzi, Chin, Henseler, \& Wang, 2010). This type of analysis determines the statistic to use and allows us to understand and assess more accurately the measurement model and the structural model technique (Henseler, Dijkstra, Sarstedt, Ringle, Diamantopoulos, Straub, Ketchen Jr, et al., 2014; Henseler, Hubona, \& Ray, 2016). According to the design and the characteristics of the questions in the questionnaire, the research was developed with variables of the reflective type. The present study used reflective variables; the main feature of this type of model is that direction and influence flow from the construct to the indicator. The observed indicators or variables are a reflection or expression of the construct, which is not observed except into a relationship (Bollen \& Lennox, 1991; Jarvis, MacKenzie, \& Podsakoff, 2003). Reflective variables are characterized by high correlations among all the indicators (co-variation), which are interchangeable; adding a new indicator does not alter the content of the construct (Jarvis et al., 2003; Wetzels, Odekerken-Schröder, \& Van Oppen, 2009).

\subsection{Independent Variable}

Corporate social responsibility. Based on our literature review, we selected the most important theories cited in studies focusing on this corporate activity as a reference to develop a CSR measurement; these theories are mentioned below: 1. The firm theory based on the use of knowledge, experience, and management skills and capabilities to increase competitiveness (profitability) and market control by means of client satisfaction, reduced costs, and beating competitors (Barney, Ketchen Jr, Wright, McWilliams, \& Siegel, 2011; Litz, 1996; McWilliams \& Siegel, 2001); 2. The sustainability theory based on economic, environmental, and social activities carried out by an organization (Dyllick \& Hockerts, 2002; Lenssen et al., 2006); and 3. The stakeholder theory that addresses (social and economic) benefits shared among the company (management and employees), 
the clients, and the community (Carroll \& Buchholtz, 2014; Friedman \& Miles, 2006). Therefore, we decided to approach the measurement of this variable from theories focused on economic and financial results and from those that propose an integrative perspective, including social and environmental activities to achieve organizational profitability. Also based on the literature, CSR was divided in three dimensions (social, environmental, and economic):

The SSR measure was developed based on studies by Carroll (1999), Lee (2008), Turker (2009) and Carroll and Shabana (2010) this variable was measured by four structured questions in the questionnaire, which were handed out to managers for them to identify and score the SSR activities their companies had carried out during the two years before the study by means of a five-point Likert scale ( $1=$ Totally disagree, $5=$ Totally agree).

The EnSR measure was adapted from studies by Jenkins (2006) and Carroll and Buchholtz (2014); six questions were developed for the questionnaire, to which again managers responded by scoring the environment-related activities their companies had carried out over the two years before the study using a five-point Likert scale ( $1=$ Totally disagree, $5=$ Totally agree).

The EcSR variable has been explored and analyzed by Friedman $(1993,2007)$ and McWilliams (2000); McWilliams et al. (2006), who wrote about the economic and financial resources allocated by companies to their social responsibility practices. This review resulted in four structured questions designed to measure the variable; again, managers responded by scoring the EcSR activities their companies had performed over the two years previous to the study using a five-point Likert scale, in which $1=$ Totally disagree and $5=$ Completely agree (see table 2).

Tabla 2. Internal consistency and convergent validity by construct

\begin{tabular}{llcc}
\hline Corporate social responsibility & FL & CR & CA \\
During the past two years, your company has: & & $\mathbf{0 . 9 1 0}$ & $\mathbf{0 . 8 6 8}$ \\
\hline SSR & & & \\
\hline Sponsored formational activities & $0.749^{* * *}$ & & \\
Sponsored public health activities & $0.862^{* * * *}$ & & $\mathbf{0 . 8 6 8}$ \\
Sponsored formational cultural activities & $0.858^{* * *}$ & & $\mathbf{0 . 8 9 9}$ \\
Made economic donations to social causes & & & \\
\hline EnSR & $0.797^{* * *}$ & & \\
\hline Sponsored environmental care activities & $0.720^{* * *}$ & & \\
Published environmental reports & $0.834^{* * *}$ & & \\
Undertaken activities to reduce pollution & $0.818^{* * *}$ & & \\
Protected the environment & $0.737^{* * *}$ & & \\
Adequately recycled its residues & $0.731^{* * *}$ & & $\mathbf{0 . 8 4 7}$ \\
Rationally used natural resources & & \\
\hline EcSR & $0.756^{* * *}$ & & \\
\hline Obtained higher economic benefits & $0.711^{* * *}$ & & \\
Achieved long-term economic success & $0.788^{* * *}$ & & \\
Established a permanent low-price policy & $0.790^{* * *}$ & & \\
Allocated resources to philanthropic activities & & \\
\hline
\end{tabular}

Note. $\mathrm{FL}=$ Factor loading, $\mathrm{CR}=$ Composite reliability, $\mathrm{CA}=$ Cronbach's alpha.

\subsection{Dependent Variable}

Profitability. Given its value and importance to companies, and also because of the complexity in its measurement, this indicator is one of the most frequently analyzed in the literature (Orlitzky, Schmidt, \& Rynes, 2003; Waddock \& Graves, 1997). Classic economic theories, for instance those focused only in the generation of wealth by resource exploitation (Fagerberg, 2003; Roberts, 2001), and the resource-based view (RBV), founded by Barney (1991), Barney (2001) and developed in studies by Kor, Mahoney, \& Michael (2007), argue that the total of tangible and intangible assets generate value and increase sales and financial results in businesses. These two are the most commonly used theories used by researchers in studies focused on organizational growth and development. More recent approaches, such as the evolutionary theory by Teece (2009), based on the dynamic capacities of companies, are moving towards the analysis of the company's context, its knowledge, and its need to develop CSR practices with the goal of becoming more innovative, profitable, and competitive over longer periods of time. The measure of CSR-related profitability was adapted from studies by Griffin \& Mahon (1997), McWilliams et al. (2006), and Barney et al. (2011); this variable was measured using three questions in the questionnaire; in these questions, the managers responded by scoring the performance results of their companies 
over the past two years. A five-point Likert-type scale was also used here (1=Poor performance, 5=High performance) (see table 3).

Table 3. Internal consistency and convergent validity by construct

\begin{tabular}{lccc}
\hline \multicolumn{1}{c}{ Profitability } & FL & CR & CA \\
During the past two years, your company has: & & & $\mathbf{0 . 8 9 9}$ \\
\hline Profitability & & & $\mathbf{0 . 8 3 1}$ \\
\hline Increased market quota & $0.834^{* * *}$ & & \\
Increased profitability & $0.857^{* * *}$ & & \\
Increased productivity & $0.902^{* * *}$ & & \\
\hline
\end{tabular}

Note. $\mathrm{FL}=$ Factor loading, $\mathrm{CR}=$ Composite reliability, $\mathrm{CA}=$ Cronbach's alpha

\subsection{Control Variables}

Size of the company. This variable was measured using the natural logarithm of total number of employees during 2013. This variable has been traditionally and frequently used in empirical studies due to its importance as a parameter of business development and business growth (Bagnoli \& Vedovato, 2014; Benitez-Amado \& Walczuch, 2012). The structural size of the company is deemed as an important factor in the generation of economic and financial performance (Jensen \& Peng, 2013; Sigler, 2011). Age of the company. Empirical studies frequently analyze this control variable within business models and associate it with economic and financial results in order to determine the influence of organizations over a set period of time (Bagnoli \& Vedovato, 2014; Benitez-Amado \& Walczuch, 2012). Company age determines how consolidated and mature a company is in the context of a market explained by the evolutionary theory (Nelson \& Winter, 2009). This variable is measured from the beginning of the company's operation to its current activities.

\subsection{Reliability and Validity}

Instrument reliability and validity was determined using a structural equation model (SEM) to avoid measurement and multicollinearity errors (Hair Jr, Black, Babin, Anderson, \& Tatham, 2010). Our study analyzed the variables in the theoretical model using a variance-based SEM, which was the best fit for our own model and research objectives. The partial least squares (PLS) method was utilized to account for the relationships between research variables with a variance-based SEM approach (Barclay, Higgins, \& Thompson, 1995; Hair Jr, Hult, Ringle, \& Sarstedt, 2013). Using the PLS method involves two phases (Barclay et al., 1995; Ringle, Sarstedt, \& Straub, 2012): Measurement model and structural model. Measurements are based on confirmatory factor analysis (CFA) in order to disregard indicators with low correlation in comparison with the rest of the scale. Additionally, we analyzed internal consistency, convergent validity, and discriminant validity (Fornell \& Larcker, 1981).

\section{Results}

\subsection{Measurement Model}

With the aim of assessing the measurement model with reflective variables, we analyzed the composite reliability, internal consistency, and convergent validity of each item. Several authors (Carmines \& Zeller, 1991; Chin \& Dibbern, 2010; Roberts, Priest, \& Traynor, 2006) recommend a standardized factor loading greater than 0.707 to measure each item's individual relation and reliability; the research values were in the range of 0.711 to 0.910 , above 0.707 . The composite reliability analysis resulted in values in the range of 0.847 to 0.910 , which meets the requirement of values greater than 0.80 for indicators as proposed by Nunnally (1978) and Vandenberg and Lance (2000) for basic research. Cronbach's alpha is considered satisfactory when above 0.70 (Hair, Black, Babin, Anderson, \& Tatham, 2006). Our results were in the range between 0.759 and 0.868 , which represents high construct reliability. Average variance extracted (AVE) indicates the mean amount of variance explained by the construct indicators. Our AVE values ranged from 0.581 to 0.748 , and these results need only be above 0.500 , as indicated by Hair Jr et al. (2010). Finally, the discriminant validity of the constructions in the model was verified by analyzing AVE square root. The results (diagonal) of the vertical and horizontal AVE are below the correlation between constructs (Henseler, Ringle, \& Sarstedt, 2015), which indicates a lack of anomalies (see table 4). The results in general demonstrate the adequate convergent and discriminant validity and reliability of the model. 
Table 4. Discriminant validity of the theoretical model

\begin{tabular}{cccccc}
\hline Construct & AVE & SSR & EnSR & EcSR & PROFITABILITY \\
\hline SSR & $\mathbf{0 . 7 1 7}$ & $\mathbf{0 . 8 4 7}$ & & & \\
EnSR & $\mathbf{0 . 5 9 9}$ & 0.555 & $\mathbf{0 . 7 7 4}$ & & \\
EcSR & $\mathbf{0 . 5 8 1}$ & 0.339 & 0.330 & $\mathbf{0 . 7 6 2}$ & \\
PROFITABILITY & $\mathbf{0 . 7 4 8}$ & 0.509 & 0.429 & 0.532 & $\mathbf{0 . 8 6 5}$ \\
\hline
\end{tabular}

\subsection{Structural Model}

The variance-based statistical technique of structural equations was employed to validate the hypotheses behind our investigation; we used the SmartPLS Professional software (version 3.2.6) (Ringle, Wende, \& Becker, 2014). This application is an adequate choice for exploratory and confirmatory investigation (Chin, 2010; Urbach \& Ahlemann, 2010). Table 5 shows $\beta$ coefficient results, degree of significance, and importance of value distribution using Student's t. Hypotheses were tested by the bootstrap procedure with 5000 subsamples, as recommended by Wynne W Chin (1998).

Table 5. Results of hypothesis testing

\begin{tabular}{lccccc}
\hline \multicolumn{1}{c}{ Hypothesis } & Value of Beta & T Score & P Value & $\mathbf{F}^{\mathbf{2}}$ & Accepted/Rejected \\
\hline H1. SSR->PROF & 0.304 & 2.482 & 0.001 & 0.105 & Accepted \\
H2. EnSR->PROF & 0.133 & 1.128 & 0.130 & 0.020 & Rejected \\
H3. EcSR->PROF & 0.385 & 3.069 & 0.007 & 0.217 & Accepted \\
\hline
\end{tabular}

Table 5 shows results of the estimation of structural equations using PLS. The study found empirical support for two of the hypotheses structured in the model ( $\mathrm{H} 1$ and $\mathrm{H} 3$ ), while none was found for $\mathrm{H} 2$. The results of hypotheses $\mathrm{H} 1$ and $\mathrm{H} 3$ showed positive and significant effects at 0.001 , by which $\mathrm{H} 1$ revealed an intense relationship between SSR and profitability in SMEs, according to the beta value of $0.304 * * *$. H2 reveals an even more intense relationship of EcSR with profitability in SMEs, as indicated by the beta value of $0.385^{* * *}$. However, hypothesis $\mathrm{H} 2$, whose beta value was 0.133 , indicates that EnSR failed to display a significant effect on profitability obtained by SMEs. Two control variables were included in the model: company size and company age. Results indicated that these two variables had no significant influence on profitability in SMEs, according to their beta values of 0.055 and -0.137 , respectively.

The covariance-based SEM techniques employed to evaluate model fitting are not yet fully developed in PLS; therefore, these measurements can only be estimated based on: 1) the value of path coefficients, 2) analysis of $\mathrm{R}^{2}$, and 3) values of $\mathrm{F}^{2}$, which are significant individual measures that explain the predictive power of the structural model (Chin, 2010). Path coefficients close to 0.2 are considered economically significant (Braojos-Gomez, Benitez-Amado, \& Llorens-Montes, 2015). The most important coefficients in our model are in the range of $0.304^{* * *}$ to $0.385^{* * *}$. The following measurement scales were used to analyze the explained variance and predictive power of the model according to $\mathrm{R}^{2}$. Values of 0.1 represent minor effects, while 0.25 represents medium effects and 0.36 represents major effects (Wetzels et al., 2009). The results of the $\mathrm{R}^{2}$ analysis of the model indicated that the profitability variable is dependent with respect to CSR practices developed by SMEs; the value of 0.394 represents the high predictive power of the model. The $\mathrm{F}^{2}$ value indicates the size of the effect introduced in the model. The values of $F^{2}: 0.02,0.15$, and 0.35 indicate minor, medium, and major effects, respectively (Leal-Rodríguez, Ariza-Montes, Roldán, \& Leal-Millán, 2014). $\mathrm{F}^{2}$ analysis results showed that the key relationships of the model had values between 0.105 and 0.217 . In general, these results show that the proposed model has adequate structural properties and good explanatory power. The $\mathrm{Q}^{2}$ cross-validated redundancy index statistical test is employed to evaluate and test the predictive relevance of endogenous constructs in structured models using reflective variables. Our model was evaluated using the blindfolding technique (Hair, Ringle, \& Sarstedt, 2013), and the resulting value was 0.335 . Values higher than zero have an outstanding predictive power (Hair et al., 2006); therefore, our model evinced a notable predictive power. In order to increase the precision of the predictive effect of our model, we also performed a goodness-of-fit test using PLS. Fit is acceptable when the standardized root mean square residual (SRMR) value is in the range $(<0,08-0,1)$ (Henseler, Dijkstra, Sarstedt, Ringle, Diamantopoulos, Straub, Ketchen, et al., 2014; Henseler et al., 2016). Our result of 0.080 confirms that the proposed model has an acceptable predictive power, and shows that 
empirical results are congruent with the theory. (See table 5).

Table 6. Predictive capacity and model fitting

\begin{tabular}{|c|c|c|c|}
\hline Dimension & $\mathbf{R}^{2}$ & $\mathbf{Q}^{2}$ & SRMR \\
\hline Profitability & 0.394 & 0.335 & 0.080 \\
\hline
\end{tabular}

\section{Discussion and Conclusion}

This section discusses our research results from the social, environmental, and economic perspectives in the light of integrative management and economic theories. From an economic point of view, firm theory has demonstrated that resources and capabilities must be directed only towards activities that will result in higher economic value (Barney et al., 2011; Demmerling, 2014). The integrative approach, related with sustainability and stakeholder theories, deals not only with financial results, but also with employee satisfaction and meeting the needs of employees, clients, society, and managers, which allows for a corporate image of social responsibility (Carroll \& Buchholtz, 2014; Crane \& Matten, 2016). From this perspective, it is the competitive and innovative companies which adopt new business models, adapt to changing markets, and develop more CSR practices (Crane, Matten, \& Spence, 2013; Jamali et al., 2017).

One of the strongest relationships revealed by the present study was that between economic CSR activities and profitability in SMEs. These results are in line with economic theory and assertions by Friedman $(1993,2007)$ and Wang \& Bansal (2012), who also highlight the significantly higher economic yield obtained by companies who engage in economic CSR activities. On the other hand, scholars in the field of CSR have argued that investors and managers are not qualified to take charge of social activities, and should direct their efforts only towards the administration of resources in the activities that result in highest economic and financial benefits for the company (Chaudhri, 2016; Ejdys, 2014). In this regard, we found a strong relationship between social CSR activities and profitability in SMEs. These results are in line with integrative theories, such as the stakeholder theory addressed by Werther Jr \& Chandler (2010) and Carroll \& Buchholtz (2014) who state that social CSR practices are vital for company growth and development, as well as for achieving more significant results in terms of profitability. Similar conclusions are discussed and supported by several empirical studies suggesting that companies should focus on the integral satisfaction of their employees, their managers, and also their communities (Johnson, 2015; Moore \& Manring, 2009). Our results are similar to the findings made by Martinez-Conesa, Soto-Acosta, \& Palacios-Manzano (2017); Reverte, Gómez-Melero, \& Cegarra-Navarro (2016), where they show that CSR is divided mainly into social and economic practices, substantially increase the profitability of companies. However we observe that in the SME, this corporate strategy is a sacrifice and a waste of resources in an exponential way (Martinez-Conesa et al., 2017). Finally, we found no significant empirical evidence for the relationship between environmental CSR activities and profitability in SMEs. Sustainability theory has shown that when companies develop CSR practices focused on preserving the natural environment, they can achieve better economic and financial results (Klewitz \& Hansen, 2014; Welford, 2013). However, our results are different: they are more in line with Friedman $(1993,2007)$, who argued that investors and organizational managers have only one main occupation: focusing on activities that produce higher economic value and not in activities that erode and wear the company's resources. The main reason behind the lack of association between EnSR activities and profitability shown by the present study could be the fact that most of the studied SMEs were focusing their efforts on short-term objectives, in the day-to-day operation and survival in highly competitive markets (Crane \& Matten, 2016; Matten \& Moon, 2008). For the most part, this has been a consequence of recent economic crises (Rüdiger, Peris-Ortiz, \& Blanco-González, 2013). In this same direction, the results reveal that the size of the company and the age of the company, do not show significant effects on the dependent variable (profitability). The theory of dynamic capabilities and economic theory mention that, as the company grows in size and age, business strategies such as CSR actions increase and consequently increase financial results (Teece, 2007; Zahra, Neubaum, \& El-Hagrassey, 2002). However, our results are not under this guideline, this is mainly due to the fact that the size of the companies under study are smaller and lack the resources and dynamic capacities to execute CSR strategies, which limits the increase of profitability (Kechiche \& Soparnot, 2012; Lepoutre \& Heene, 2006).

This article analyzed the influence of three types of CSR practices - their social, environmental, and economic dimensions - on profitability obtained by SMEs. In response to the research questions and goal of the present study, the results of the present study indicated that: 1) social CSR practices are being adequately carried out by SMEs, and these activities are driving them toward significant financial and economic outcomes; 2) economic CSR practices are also contributing to profitability by means of an accurate development and management of 
such practices, and 3) despite SMEs are not focusing on environmental CSR practices, social and economic CSR practices have an effect on their performance. The implications of this study represent an important breakthrough for SMEs to increase CSR practices and enhance their corporate management. Business owners, along with leaders, should adopt corporate strategies and new business models allowing for higher competitiveness and profitability. This can be achieved, in the first place, by implementing new approaches into the business, such as green business strategies and process-improving practices, for instance pursuing social responsibility and quality certifications on ISO (International Organization for Standardization) norms (Battisti \& Perry, 2011; Husted \& Allen, 2010; Morrow \& Rondinelli, 2002). Secondly, it is possible for managers to raise profitability levels by finding a balance between the social, environmental, and economic dimensions of their companies; this will also result in fully meeting stakeholders' needs (Carroll \& Buchholtz, 2014; Werther Jr \& Chandler, 2010). The management should recognize the importance of deploying an organizational culture based on values and corporate ethics focused on creating benefits for natural and social ecosystems, since this course of action can lead the organization to significant operational and economic results in the middle term (Carroll \& Buchholtz, 2014; Litz, 1996).

Although the present study has opened room for important developments in this line of investigation, it presents some limitations. One of the limitations derives from the use of only one source of information. The data consisted in subjective perceptions expressed by SME business owners and managers, so results could have been biased; this is an opportunity to take into account the opinion of other stakeholders, such as employees, clients, suppliers, and society itself in order to compare results. Another limitation is the sample selection, which consisted only on companies in the industrial and services sectors, although the method could naturally be extended to other types of companies. The last limitation has to do with the measurement scales employed to measure CSR: we considered only reflective variables adapted from scales in other studies, based on different theoretical streams. To overcome those limitations, future studies should include more constructs in the analysis of competitiveness and CSR practices in SMEs. Finally, given the relevance of CSR and the controversy around its implementation at times of intense competition, our line of investigation will continue studying the relationship of competitiveness with innovation, market orientation, corporate image and reputation, and financial and non-financial profitability. In addition, it would be interesting to analyze other control variables and their relation to performance, such as the business sector and the leadership style of SME managers, in order to complement this type of research. Indicators of performance, growth, and competitiveness in SMEs will remain under permanent assessment.

\section{Acknowledgement}

Research project funded by PFCE "The resources of the PFCE are of a public nature and it is prohibited to use them for partisan or personal promotion purposes".

\section{References}

Attig, N., El Ghoul, S., Guedhami, O., \& Suh, J. (2013). Corporate social responsibility and credit ratings. Journal of Business Ethics, 117(4), 679-694. https://doi.org/10.1007/s10551-013-1714-2

Bagnoli, C., \& Vedovato, M. (2014). The impact of knowledge management and strategy configuration coherence on SME performance. Journal of Management \& Governance, 18(2), 615-647. https://doi.org/10.1007/s10997-012-9211-z

Banerjee, S. B. (2008). Corporate social responsibility: The good, the bad and the ugly. Critical Sociology, 34(1), 51-79. https://doi.org/10.1177/0896920507084623

Barclay, D., Higgins, C., \& Thompson, R. (1995). The partial least squares (PLS) approach to causal modeling: Personal computer adoption and use as an illustration. Technology Studies, 2(2), 285-309.

Barney, J. (1991). Firm Resources and Sustained Competitive Advantage. Journal of Management, 17(1), 99-120. https://doi/ 10.1177/014920639101700108

Barney, J. B. (2001). Resource-based theories of competitive advantage: A ten-year retrospective on the resource-based view. Journal of Management, 27(6), 643-650. https://doi.org/10.1177/014920630102700602

Barney, J. B., Ketchen, J. D. J., Wright, M., McWilliams, A., \& Siegel, D. S. (2011). Creating and capturing value: Strategic corporate social responsibility, resource-based theory, and sustainable competitive advantage. Journal of Management, 37(5), 1480-1495. https://doi.org/10.1177/0149206310385696

Battisti, M., \& Perry, M. (2011). Walking the talk? Environmental responsibility from the perspective of small-business owners. Corporate Social Responsibility and Environmental Management, 18(3), 172-185. https://doi.org/10.1002/csr.266 
Beal, B. D. (2013). Corporate Social Responsibility: Definition, Core Issues, and Recent Developments. London: SAGE Publications.

Benitez-Amado, J., \& Walczuch, R. M. (2012). Information technology, the organizational capability of proactive corporate environmental strategy and firm performance: a resource-based analysis. European Journal of Information Systems, 21(6), 664-679. https://doi.org/10.1057/ejis.2012.14

Benn, S., Dunphy, D., \& Griffiths, A. (2014). Organizational change for corporate sustainability. New York: Routledge.

Bhimani, A., Silvola, H., \& Sivabalan, P. (2016). Voluntary corporate social responsibility reporting: A study of early and late reporter motivations and outcomes. Journal of Management Accounting Research, 28(2), 77-101. https://doi.org/10.2308/jmar-51440

Blowfield, M. E., \& Murray, A. (2008). Corporate responsibility: A critical overview. Oxford: Oxford University Press.

Blowfield, M., \& Murray, A. (2014). Corporate responsibility. Oxford: Oxford University Press.

Bollen, K., \& Lennox, R. (1991). Conventional wisdom on measurement: A structural equation perspective. Psychological Bulletin, 110(2), 305-314. https://doi/ 10.1037/0033-2909.110.2.305

Bos-Brouwers, H. E. J. (2010). Corporate sustainability and innovation in SMEs: evidence of themes and activities in practice. Business Strategy and the Environment, 19(7), 417-435.

Bowen, H. R. (2013). Social responsibilities of the businessman. Iowa: University of Iowa Press.

Braojos-Gomez, J., Benitez-Amado, J., \& Llorens-Montes, F. J. (2015). How do small firms learn to develop a social media competence? International Journal of Information Management, 35(4), 443-458. https://doi.org/10.1016/j.ijinfomgt.2015.04.003

Carmines, E. G., \& Zeller, R. A. (1991). Reliability and viability assessment. CA: Thousand Oaks.

Carroll, A. B. (1979). A three-dimensional conceptual model of corporate performance. Academy of management review, 4(4), 497-505.

Carroll, A. B. (1999). Corporate social responsibility evolution of a definitional construct. Business \& Society, 38(3), 268-295. https://doi.org/10.1177/000765039903800303

Carroll, A. B. (2008). A history of corporate social responsibility: Concepts and practices. The Oxford handbook of corporate social responsibility, 19-46.

Carroll, A. B, \& Shabana, K. M. (2010). The business case for corporate social responsibility: A review of concepts, research and practice. International Journal of Management Reviews, 12(1), 85-105. https://doi.org/10.1111/j.1468-2370.2009.00275.x

Carroll, A., \& Buchholtz, A. (2014). Business and society: Ethics, sustainability, and stakeholder management. Toronto: Nelson Education.

Carroll, C. E. (2011). Media relations and corporate social responsibility. The handbook of communication and corporate social responsibility, 423-444. https://doi.org/10.1002/9781118083246.ch21

Castejón, P. J. M., \& López, B. A. (2016). Corporate social responsibility in family SMEs: A comparative study. European Journal of Family Business, 6(1), 21-31. https://doi.org/10.1016/j.ejfb.2016.05.002

Coppa, M., \& Sriramesh, K. (2013). Corporate social responsibility among SMEs in Italy. Public Relations Review, 39(1), 30-39. https://doi.org/10.1016/j.pubrev.2012.09.009

Crane, A., \& Matten, D. (2016). Business ethics: Managing corporate citizenship and sustainability in the age of globalization. Oxford: Oxford University Press.

Crane, A., Matten, D., \& Spence, L. J. (2013). Corporate social responsibility in a global context. Chapter in: Crane, A., Matten, D., and Spence, L. J., Corporate Social Responsibility: Readings and Cases in a Global Context, 2, 3-26.

Chaudhri, V. (2016). Corporate social responsibility and the communication imperative: Perspectives from CSR managers. International Journal of Business Communication, 53(4), 419-442. https://doi.org/10.1177/2329488414525469

Chin, W. W. (1998). The partial least squares approach to structural equation modeling. Modern Methods for Business Research, 295(2), 295-336. 
Chin, W. W., \& Dibbern, J. (2010). An introduction to a permutation based procedure for multi-group PLS analysis: Results of tests of differences on simulated data and a cross cultural analysis of the sourcing of information system services between Germany and the USA Handbook of partial least squares (pp. 171-193). Berlin: Springer.

Chin, W. W. (2010). How to Write Up and Report PLS Analyses. 655-690. https://doi/10.1007/978-3-540-32827-8_29

Demmerling, T. (2014). Corporate Social Responsibility Overload? Intention, Abuse, Misinterpretation of CSR from the Companies' and the Consumers' Point of View. Anchor Academic Publishing.

Dyllick, T., \& Hockerts, K. (2002). Beyond the business case for corporate sustainability. Business Strategy and the Environment, 11(2), 130-141. https://doi.org/10.1002/bse.323

Ejdys, J. (2014). Future oriented strategy for SMEs. Procedia-Social and Behavioral Sciences, 156, 8-12. https://doi.org/10.1016/j.sbspro.2014.11.110

Ejdys, J. (2017). The Role of Internal Stakeholders in the Process of Creation Social Responsible Long-Term Care System in Poland. Paper presented at the Country Experiences in Economic Development, Management and Entrepreneurship: Proceedings of the 17th Eurasia Business and Economics Society Conference. https://doi.org/10.1007/978-3-319-46319-3_46

El Baz, J., Laguir, I., Marais, M., \& Staglianò, R. (2016). Influence of national institutions on the corporate social responsibility practices of Small-and Medium-sized Enterprises in the food-processing industry: Differences between France and Morocco. Journal of Business Ethics, 134(1), 117-133. https://doi.org/10.1007/s10551-014-2417-z

Fagerberg, J. (2003). Schumpeter and the revival of evolutionary economics: an appraisal of the literature. Journal of Evolutionary Economics, 13(2), 125-159. https://doi.org/10.1007/s00191-003-0144-1

Fitch, H. G. (1976). Achieving corporate social responsibility. Academy of Management Review, 1(1), 38-46. https://doi.org/10.5465/AMR.1976.4408754

Fontrodona, J., \& Sison, A. J. G. (2006). The nature of the firm, agency theory and shareholder theory: A critique from philosophical anthropology. Journal of Business Ethics, 66(1), 33-42. https://doi.org/10.1007/s10551-006-9052-2

Fornell, C., \& Larcker, D. F. (1981). Structural equation models with unobservable variables and measurement error: Algebra and statistics. Journal of Marketing Research, 382-388. https://doi.org/10.2307/3150980

Freeman, I., \& Hasnaoui, A. (2011). The meaning of corporate social responsibility: The vision of four nations. Journal of Business Ethics, 100(3), 419-443. https://doi.org/10.1007/s10551-010-0688-6

Freeman, R. E., \& Liedtka, J. (1991). Corporate social responsibility: A critical approach. Business Horizons, 34(4), 92-98. https://doi.org/10.1016/0007-6813(91)90012-K

Freeman, R. E., \& Velamuri, S. R. (2008). A new approach to CSR: Company stakeholder responsibility.

Friedman, A. L, \& Miles, S. (2006). Stakeholders: Theory and practice. Oxford: Oxford University Press on Demand.

Friedman, B. M. (2006). The moral consequences of economic growth. Society, 43(2), 15-22. https://doi.org/10.1007/BF02687365

Friedman, M. (1993). The Social Responsibility of Business is to Increase it Profits. London: Chapman \& Hall.

Friedman, M. (2007). The social responsibility of business is to increase its profits Corporate ethics and corporate governance (pp. 173-178). Berlin: Springer.

Garriga, E., \& Melé, D. (2004). Corporate social responsibility theories: Mapping the territory. Journal of Business Ethics, 53(1), 51-71. https://doi.org/10.1023/B:BUSI.0000039399.90587.34

Geva, A. (2008). Three models of corporate social responsibility: Interrelationships between theory, research, and practice. Business and Society Review, 113(1), 1-41. https://doi.org/10.1111/j.1467-8594.2008.00311.x

Grant, R. M. (2016). Contemporary strategy analysis: Text and cases edition. Hoboken, Nj: John Wiley \& Sons.

Griffin, J. J., \& Mahon, J. F. (1997). The corporate social performance and corporate financial performance debate: Twenty-five years of incomparable research. Business \& Society, 36(1), 5-31. https://doi.org/10.1177/000765039703600102 
Hair, J. F., Black, W. C., Babin, B. J., Anderson, R. E., \& Tatham, R. L. (2006). Multivariate Data Analysis (Vol. 6): Upper Saddle River, NJ: Pearson Prentice Hall.

Hair, J. F., Ringle, C. M., \& Sarstedt, M. (2013). Editorial-partial least squares structural equation modeling: Rigorous applications, better results and higher acceptance. Long Range Planning, 46(1-2), 1-12. https://doi.org/10.1016/j.lrp.2013.01.001

Hair, J. J. F., Black, W. C., Babin, B. J., Anderson, R. E., \& Tatham, R. L. (2010). SEM: An introduction. Multivariate data analysis: A global perspective, 629-686.

Hair, J. J. F., Hult, G., Tomas, M., Ringle, C., \& Sarstedt, M. (2013). A primer on partial least squares structural equation modeling (PLS-SEM). London:L Sage Publications.

Henseler, J. D., Theo, K. S., Marko, R., Christian, M., Diamantopoulos, A., Straub, D. W., ... Calantone, R. J. (2014). Common beliefs and reality about PLS: Comments on Rönkkö and Evermann (2013). Organizational Research Methods, 17(2), 182-209. https://doi.org/10.1177/1094428114526928

Henseler, J., Hubona, G., \& Ray, P. A. (2016). Using PLS path modeling in new technology research: updated guidelines. Industrial Management \& Data Systems, $116(1), \quad 2-20$. https://doi.org/10.1108/IMDS-09-2015-0382

Henseler, J., Ringle, C. M., \& Sarstedt, M. (2015). A new criterion for assessing discriminant validity in variance-based structural equation modeling. Journal of the Academy of Marketing Science, 1-21. https://doi.org/10.1007/s11747-014-0403-8

Hoogendoorn, B., Guerra, D., \& Van Der Zwan, P. (2015). What drives environmental practices of SMEs? Small Business Economics, 44(4), 759-781. https://doi.org/10.1007/s11187-014-9618-9

Husted, B. W., \& Allen, D. B. (2010). Corporate Social Strategy: Stakeholder Engagement and Competitive Advantage. Cambridge: Cambridge University Press. https://doi.org/10.1017/CBO9780511667060

INEGI. (2014). Instituto Nacional de Estadística, Geografía E informática. Censo Económico del Directorio Estadístico Nacional de Unidades Económicas (DENUE). Retrieved from http://www.beta.inegi.org.mx/app/mapa/denue/default.aspx

Jamali, D., Lund-Thomsen, P., \& Jeppesen, S. (2017). SMEs and CSR in developing countries. Business \& Society, 56(1), 11-22. https://doi.org/10.1177/0007650315571258

Jarvis, C. B., MacKenzie, S. B., \& Podsakoff, P. M. (2003). A critical review of construct indicators and measurement model misspecification in marketing and consumer research. Journal of Consumer Research, 30(2), 199-218. https://doi.org/10.1086/376806

Jenkins, H. (2006). Small business champions for corporate social responsibility. Journal of Business Ethics, 67(3), 241-256. https://doi.org/10.1007/s10551-006-9182-6

Jensen, C., \& Peng, L. M. (2013). SMEs, Institutions, and Performance. Small and Medium Enterprises: Concepts, Methodologies, Tools, and Applications, 46.

Johnson, M. P. (2015). Sustainability Management and Small and Medium - Sized Enterprises: Managers' Awareness and Implementation of Innovative Tools. Corporate Social Responsibility and Environmental Management, 22(5), 271-285. https://doi.org/10.1002/csr.1343

Jorge, M. L., Madueño, J. H., Cejas, M. Y. C., \& Peña, F. J. A. (2015). An approach to the implementation of sustainability practices in Spanish universities. Journal of Cleaner Production, 106, 34-44. https://doi.org/10.1016/j.jclepro.2014.07.035

Kechiche, A., \& Soparnot, R. (2012). CSR within SMEs: Literature review. International Business Research, 5(7), 97. https://doi.org/10.5539/ibr.v5n7p97

Klewitz, J., \& Hansen, E. G. (2014). Sustainability-oriented innovation of SMEs: a systematic review. Journal of Cleaner Production, 65, 57-75. https://doi.org/10.1016/j.jclepro.2013.07.017

Kor, Y. Y., Mahoney, J. T, \& Michael, S. C. (2007). Resources, capabilities and entrepreneurial perceptions. Journal of Management Studies, 44(7), 1187-1212. https://doi.org/10.1111/j.1467-6486.2007.00727.x

Kramer, M. R., \& Porter, M. E. (2006). Estrategia y sociedad: el vínculo entre ventaja competitiva y responsabilidad social corporativa. Harvard Business Review, 84(12), 42-56.

Krüger, P. (2015). Corporate goodness and shareholder wealth. Journal of Financial Economics, 115(2), 304-329. https://doi.org/10.1016/j.jfineco.2014.09.008 
Leal-Rodríguez, A. L., Ariza-Montes, J. A., Roldán, J. L., \& Leal-Millán, A. G. (2014). Absorptive capacity, innovation and cultural barriers: A conditional mediation model. Journal of Business Research, 67(5), 763-768. https://doi.org/10.1016/j.jbusres.2013.11.041

Lee, M. D. P. (2008). A review of the theories of corporate social responsibility: Its evolutionary path and the road ahead. International Journal of Management Reviews, 10(1), 53-73. https://doi.org/10.1111/j.1468-2370.2007.00226.x

Lenssen, G., Gasparski, W., Rok, B., Lacy, P., \& Eberhard-Harribey, L. (2006). Corporate social responsibility as a new paradigm in the European policy: how CSR comes to legitimate the European regulation process. Corporate Governance: The International Journal of Business in Society, 6(4), 358-368. https://doi.org/10.1108/14720700610689487

Lepoutre, J., \& Heene, A. (2006). Investigating the impact of firm size on small business social responsibility: A critical review. Journal of Business Ethics, 67(3), 257-273. https://doi.org/10.1007/s10551-006-9183-5

Litz, R. A. (1996). A resource-based-view of the socially responsible firm: Stakeholder interdependence, ethical awareness, and issue responsiveness as strategic assets. Journal of Business Ethics, 15(12), 1355-1363. https://doi.org/10.1007/BF00411820

Lozano, R., \& Huisingh, D. (2011). Inter-linking issues and dimensions in sustainability reporting. Journal of Cleaner Production, 19(2), 99-107. https://doi.org/10.1016/j.jclepro.2010.01.004

Luo, X., Wang, H., Raithel, S., \& Zheng, Q. (2015). Corporate social performance, analyst stock recommendations, and firm future returns. Strategic Management Journal, 36(1), 123-136. https://doi.org/10.1002/smj.2219

Ma, J. (2012). A study on the models for corporate social responsibility of small and medium enterprises. Physics Procedia, 25, 435-442. https://doi.org/10.1016/j.phpro.2012.03.108

Madorran, C., \& Garcia, T. (2016). Corporate social responsibility and financial performance: the spanish case. Revista de Administração de Empresas, 56(1), 20-28. https://doi.org/10.1590/S0034-759020160103

Maignan, I., \& Ferrell, O. C. (2004). Corporate social responsibility and marketing: An integrative framework. Journal of the Academy of Marketing Science, 32(1), 3-19. https://doi.org/10.1177/0092070303258971

Maldonado-Guzman, G., Pinzon-Castro, S. Y., \& Lopez-Torres, G. C. (2016). Corporate social responsibility and business performance: The role of mexican SMEs. International Journal of Asian Social Science, 6(10), 568-579. https://doi.org/10.18488/journal.1/2016.6.10/1.10.568.579

Marín, L., Rubio, A., \& Maya, S. R. (2012). Competitiveness as a strategic outcome of corporate social responsibility. Corporate Social Responsibility and Environmental Management, 19(6), 364-376. https://doi.org/10.1002/csr.1288

Martinez-Conesa, I., Soto-Acosta, P., \& Palacios-Manzano, M. (2017). Corporate social responsibility and its effect on innovation and firm performance: An empirical research in SMEs. Journal of Cleaner Production, 142, 2374-2383. https://doi.org/10.1016/j.jclepro.2016.11.038

Martínez, A. R., Fuentes, J. M., \& Delgado, J. J. J. (2015). Estado actual de la investigación en Responsabilidad Social Corporativa a nivel organizativo: consensos y desafíos futuros/État actuel de la recherche en matière de responsabilité sociale des entreprises au niveau organisationnel: Consensus et défis futurs/The current state of research into Corporate Social Responsibility at the organisational level: areas of consensus and future challenges. CIRIEC-Espana, (85), 143.

Matten, D., \& Moon, J. (2008). "Implicit" and "explicit" CSR: A conceptual framework for a comparative understanding of corporate social responsibility. Academy of Management Review, 33(2), 404-424. https://doi.org/10.5465/AMR.2008.31193458

McWilliams, A. (2000). Corporate social responsibility. Wiley Encyclopedia of Management.

McWilliams, A., \& Siegel, D. (2001). Corporate social responsibility: A theory of the firm perspective. Academy of Management Review, 26(1), 117-127.

McWilliams, A., Siegel, D. S., \& Wright, P. M. (2006). Corporate social responsibility: Strategic implications*. Journal of Management Studies, 43(1), 1-18. https://doi.org/10.1111/j.1467-6486.2006.00580.x

Moore, S. B., \& Manring, S. L. (2009). Strategy development in small and medium sized enterprises for sustainability and increased value creation. Journal of Cleaner Production, 17(2), 276-282. https://doi.org/10.1016/j.jclepro.2008.06.004 
Morrow, D., \& Rondinelli, D. (2002). Adopting corporate environmental management systems:: Motivations and results of ISO 14001 and EMAS certification. European Management Journal, 20(2), 159-171. https://doi.org/10.1016/S0263-2373(02)00026-9

Nelson, R. R., \& Winter, S. G. (2009). An evolutionary theory of economic change. Harvard: Harvard University Press.

Nunnally, J. (1978). Psychometric methods. New York: McGraw-Hill.

Nwachukwu, S. L. S., Vitell, S. J., Gilbert, F. W., \& Barnes, J. H. (1997). Ethics and social responsibility in marketing: an examination of the ethical evaluation of advertising strategies. Journal of Business Research, 39(2), 107-118. https://doi.org/10.1016/S0148-2963(96)00146-4

O'riordan, L., \& Fairbrass, J. (2008). Corporate social responsibility (CSR): Models and theories in stakeholder dialogue. Journal of Business Ethics, 83(4), 745-758. https://doi.org/10.1007/s10551-008-9662-y

OECD. (2011). Organisation for Economic Co-operation and Development. Guidelines for Multinational Enterprises, 2011 Edition. OECD Publishing.

Orlitzky, M., Schmidt, F. L., \& Rynes, S. L. (2003). Corporate social and financial performance: A meta-analysis. Organization Studies, 24(3), 403-441. https://doi.org/10.1177/0170840603024003910

Pedersen, E. R. (2010). Modelling CSR: How managers understand the responsibilities of business towards society. Journal of Business Ethics, 91(2), 155-166. https://doi.org/10.1007/s10551-009-0078-0

Podsakoff, P. M., \& Organ, D. W. (1986). Self-reports in organizational research: Problems and prospects. Journal of Management, 12(4), 531-544. https://doi.org/10.1177/014920638601200408

Porter, M. E., \& Kramer, M. R. (2011). The big idea: Creating shared value. Harvard Business Review, 89(1), 2.

Reio, J. T. G. (2010). The threat of common method variance bias to theory building. Human Resource Development Review, 9(4), 405-411. https://doi.org/10.1177/1534484310380331

Reverte, C., Gómez-Melero, E., \& Cegarra-Navarro, J. G. (2016). The influence of corporate social responsibility practices on organizational performance: evidence from Eco-Responsible Spanish firms. Journal of Cleaner Production, 112, 2870-2884. https://doi.org/10.1016/j.jclepro.2015.09.128

Ringle, C. M., Sarstedt, M., \& Straub, D. (2012). A critical look at the use of PLS-SEM in MIS Quarterly. MIS Quarterly (MISQ), 36(1).

Ringle, C. M., Wende, S., \& Becker, J. M. (2014). SmartPLS 3. SmartPLS, Hamburg.

Roberts, P., Priest, H., \& Traynor, M. (2006). Reliability and validity in research. Nursing Standard, $20(44), 41$. https://doi.org/10.7748/ns.20.44.41.s56

Roberts, P. W. (2001). Innovation and firm-level persistent profitability: a Schumpeterian framework. Managerial and Decision Economics, 22(4-5), 239-250. https://doi.org/10.1002/mde.1018

Rüdiger, K., Peris-Ortiz, M., \& Blanco-González, A. (2013). Entrepreneurship, Innovation and Economic Crisis: Lessons for Research, Policy and Practice. Berlin: Springer International Publishing.

Sigler, K. J. (2011). CEO Compensation and company performance. Business and Economic Journal, 2011, 1-8.

Soytas, M. A., Denizel, M., \& Usar, D. (2016). Corporate Sustainability: Empirical Evidence of Causality on Financial Performance.

Teece, D. J. (2007). Explicating dynamic capabilities: the nature and microfoundations of (sustainable) enterprise performance. Strategic Management Journal, 28(13), 1319-1350. https://doi.org/10.1002/smj.640

Teece, D. J. (2009). Dynamic capabilities and strategic management: organizing for innovation and growth. Oxford: OUP.

Turker, Duygu. (2009). Measuring corporate social responsibility: A scale development study. Journal of Business Ethics, 85(4), 411-427. https://doi.org/10.1007/s10551-008-9780-6

Urbach, N., \& Ahlemann, F. (2010). Structural equation modeling in information systems research using partial least squares. Journal of Information Technology Theory and Application, 11(2), 5-40.

Vandenberg, R. J., \& Lance, C. E. (2000). A review and synthesis of the measurement invariance literature: Suggestions, practices, and recommendations for organizational research. Organizational Research Methods, 3(1), 4-70. https://doi.org/10.1177/109442810031002

Vinzi, V. E., Chin, W. W., Henseler, J., \& Wang, H. (2010). Handbook of partial least squares: Concepts, methods 
and applications. Berlin: Springer Science \& Business Media. https://doi.org/10.1007/978-3-540-32827-8

Virvilaite, R., \& Daubaraite, U. (2015). Corporate social responsibility in forming corporate image. Engineering Economics, 22(5), 534-543.

Waddock, S. A., \& Graves, S. B. (1997). The corporate social performance-financial performance link. Strategic Management Journal, 303-319. https://doi.org/10.1002/(SICI)1097-0266(199704)18:4\%3C303::AID-SMJ869\%3E3.0.CO;2-G

Wang, T., \& Bansal, P. (2012). Social responsibility in new ventures: profiting from a long-term orientation. Strategic Management Journal, 33(10), 1135-1153. https://doi.org/10.1002/smj.1962

Welford, R. (2013). Hijacking environmentalism: Corporate responses to sustainable development. London: Routledge.

Werther, J. W. B., \& Chandler, D. (2010). Strategic corporate social responsibility: Stakeholders in a global environment. Thousand Oaks: Sage Publications.

Wetzels, M., Odekerken-Schröder, G., \& Van Oppen, C. (2009). Using PLS path modeling for assessing hierarchical construct models: Guidelines and empirical illustration. MIS quarterly, 177-195.

Zahra, S. A., Neubaum, D. O., \& El-Hagrassey, G. M. (2002). Competitive analysis and new venture performance: Understanding the impact of strategic uncertainty and venture origin. Entrepreneurship Theory and Practice, 27(1), 1-28. https://doi.org/10.1111/1540-8520.t01-2-00001

\section{Copyrights}

Copyright for this article is retained by the author(s), with first publication rights granted to the journal.

This is an open-access article distributed under the terms and conditions of the Creative Commons Attribution license (http://creativecommons.org/licenses/by/4.0/). 